\title{
IMPLEMENTASI CORPORATE SOCIAL RESPONSIBILITY (CSR) PT. PERTAMINA (PERSERO) MARKETING OPERATION REGION (MOR) I - TERMINAL BAHAN BAKAR MINYAK (TBBM) SIANTAR: PEMBERDAYAAN EKONOMI MASYARAKAT BERBASIS POTENSI LOKAL MELALUI PROGRAM BANGUN INDUSTRI DESA (BID)
}

\author{
Andri Zainal $^{1 *}$, Tengku Citra Nisa Farza ${ }^{1}$, Roza Thohiri $^{1}$, Pasca Dwi Putra ${ }^{1}$ \\ ${ }^{1}$ Fakultas Ekonomi, Universitas Negeri Medan, Medan, Indonesia \\ *Penulis Korespondensi: andrizainal@unimed.ac.id
}

\begin{abstract}
Abstrak
Pendekatan pemberdayaan masyarakat telah terbukti menjadi alat yang kuat untuk memecahkan masalah rendahnya pengembalian ekonomi dari industri kecil di suatu daerah. Namun, metode untuk mengukur pemberdayaan di masyarakat tetap tidak jelas dan terbuka untuk diperdebatkan. Penelitian ini bertujuan untuk mendeskripsikan bagaimana keberhasilan pemberdayaan masyarakat terhadap potensi lokal di Kota Pematang Siantar (dilihat dari usaha produksi ice cream, susu kambing dan tenunan ulos asli batak) yang diterapkan melalui program BID melalui skema CSR PT. PERTAMINA (Persero) MOR I - TBBM Siantar di wilayah administratif Kota Pematang Siantar. Hasil analisis studi menunjukkan implikasi program BID dan CSR mampu memberikan dampak positif kepada masyarakat Kota Pematang Siantar melalui peningkatan ekonomi dan perubahan budaya. Peningkatan ekonomi dimaknai sebagai peningkatan pendapatan ekonomi masyarakat sebagai dapmak positif dari peningkatan kualitas produk yang dihasilkan setelah pelaksanaan pemberdayaan masyarakat. Peningkatan pendapatan dirasakan oleh anggota kelompok penggiat susu kambing, ice cream dan penenun ulos asli batak. Perubahan budaya yakni perubahan ke arah sikap mental wirausaha telah nampak pada pelaku usaha, seperti memiliki visi, mampu membaca peluang, dan percaya diri.
\end{abstract}

Kata Kunci: Pemberdayaan Masyarakat, BID, CSR, Industri Kecil Kota Pematang Siantar

\begin{abstract}
The community empowerment approach is proven to be a powerful tool in solving problems relevant to low economic returns gained by an operation of small industries in an area. This study aims to describe key success practices on the implementation of community based local potential empowerment in Pematang Siantar City (highlightig production of ice cream, goat milk of Etawa and batak native Ulos) that is formed in the BID scheme supported by an CSR scheme from PT. PERTAMINA (Persero) MOR I - TBBM Siantar. The results of qualitative study show that the implications of BID backed-up by the CSR of PT. PERTAMINA (Persero) MOR I - TBBM Siantar. Positively contributed to the refinement of economic and business related-activities among involved industries underlining significant improvements on the quality of products manufactured by the CSR beneficiaries: ice cream, goat milk of Etawa and Batak native Ulos; as well as beneficiaries' financial benefits. This community empowerment program has also affected to changes in the attitude of entrepreneurial mentality indicated from better and stronger of vision, ability in overcoming potential business opportunities, and self-confident in conducting business independently and professionally.
\end{abstract}

Keywords: Community Empowerment, BID, CSR, Small Industry of Pematang Siantar City

\section{PENDAHULUAN}

Berbagai permasalahan manajemen pengolahan dan pemasaran yang dihadapi industri kecil tersebut tentunya berpengaruh terhadap penggunaan waktu produksi yang cenderung lama sehingga berdampak pada jumlah produksi yang tidak maksimal. Jangkauan pemasaran yang tidak luas serta kualitas yang belum mapu bersaing akan berimbas pada rendahnya pendapatan ekonomi masyarakat di Kota Pematang Siantar. Data BPS menunjukkan laju pertumbuhan
PDRB Kota Pematang Siantar dari tahun 2015-2017 terus mengalami penurunan dari 5,24 persen pada tahun 2015 menjadi 4,86 persen pada tahun 2016 dan terus menurun menjadi 4,41 persen pada tahun 2017. Rendahnya pendapatan Kota Pematang Siantar berdampak pada meningkatnya persentase penduduk miskin pada tahun 2016 sebesar 9,99 persen meningkat menjadi 10,10 persen pada tahun 2017.

Berbagai upaya pengentasan kemiskinan tentunya sudah digalakkan oleh berbagai sektor mulai dari sektor 
pemerintahan dengan program-program unggulannya hingga Lembaga Swadaya Masyarakat melalui usaha yang dilakukan dengan tujuan mengurangi angka kemiskinan dan mensejahterakan masyarakat, termasuk dengan jalan pemberdayaan masyarakat. Pemberdayaan masyarakat dapat diwujudkan dalam berbagai program seperti program Bangun Industri Desa (BID) yang secara khusus direalisasikan dalam bentuk penyaluran CSR oleh PT. PERTAMINA (Persero) MOR I - TBBM Siantar di Keluarahan Banjar, Kelurahan Bahkapul, Kelurahan Naga Pita dan Kelurahan Aek Nauli. Program CSR ini selain sebagai pengejawantahan kepatuhan korporasi pada perangkat hukum yang terkait - Undang-Undang No. 40 Tahun 2007 tentang Perseroan Terbatas (UUPT) serta Peraturan Pemerintah No. 47 Tahun 2012 tentang Tanggung Jawab Sosial dan Lingkungan (TJSL) Perseroan Terbatas (PP 47/2012) - juga menjadi penguatan eksistensi korporasi dalam pemberdayaan Masyarakat yang berkontribusi kepada peningkatan kesejahteraan perekonomian masyarakat di Kota Pematang Siantar. Di sisi lain dengan adanya BID yang mencakup berbagai program pemberdayaan masyarakat yang memberikan manfaat signifikan bagi masyarakat. Salah satu daerah yang telah berhasil dalam program CSR yaitu pada budi daya keramba ikan air tawar di Desa Sarijaya Kabupaten Kutai Kartanegara, yang dilaksanakan PT Pertamina EP Field Sanga-Sanga cukup berhasil dengan indeks capaian diatas angka 85 persen, jika dinilai dari empat aspek yang digunakan: baik secara manfaat, kesesuaian, keberlanjutan, dan aspek dampak yang dihasilkan (Pranoto, \& Yusuf, 2014).

Oleh karena itu, kajian ini membahas tentang implementasi program BID sebagai bagian dari implementasi CSR sebagai salah satu perwujudan pemberdayaan masyarakat dalam memandirikan masyarakat di Kota Pematang Siantar. Penelitian ini menjadi penting karena akan menganalisis bentuk pemberdayaan masyarakat berbasis potensi lokal yaitu usaha ice cream, susu kambing dan kerajinan ulos asli batak di Kota Pematang Siantar. Dengan adanya kajian ini akan memberikan wawasan dalam rangka pengembangan idustri kecil sehingga masyarakat dapat memanfaatkan potensi lokal yang ada di daerahnya. Penelitian ini bermaksud untuk mengetahui lebih dalam tentang keberhasilan program BID dan CSR terhadap pemberdayaan ekonomi masyarakat di Kota Pematang Siantar.

\section{INDUSTRI KECIL SEBAGAI POTENSI OPTIMALISASI EKONOMI LOKAL KOTA PEMATANG SIANTAR}

\subsection{Industri Susu Kambing}

Sistem peternakan kambing di Indonesia berbeda-beda untuk setiap daerah, ada yang sudah menerapkan sistem modern, semi-modern dan tradisional dalam sistem perternakan kambingnya. Di Kota Pematang Siantar tepatnya di Kelurahan Bahkapul, sistem peternakan kambing yang dijalan oleh masyarakat sekitar masih tradisional. Para peternak kambing lebih cenderung untuk memerah susu kambing dan daging kambing daripada pembibitan susu kambing. Peternakan mengelola 60 ekor kambing dan hanya 20 ekor kambing yang dapat menghasilkan perahan susu, perahan susu bisa menghasilkan 4,5 liter per hari. Hasil perahan susu ini dijual dalam kemasan berebtuk botol dengan ukuran $230 \mathrm{ml}$ dengan harga 15.000/botol. Perahan susu kambing hanya bertahan sekitar 4-5 jam tanpa freezer dan akan bertahan sampai dengan 2 hari dengan menggunakan freezer.

Di sisi lain karena belum banyaknya yang mengetahui bahwa kambing peranakan etawa mempunyai kemampuan yang cukup tinggi sebagai peternak perah, sehingga potensi tersebut belum dimanfaatkan secara optimal oleh peternak kambing di Kelurahan Bahkapul. Pengembangan kambing ini dalam skala yang lebih luas dan lebih besar akan dapat membantu meningkatkan kesejahteraan peternak, dari produksi susu yang selama ini belum dimanfaatkan.

Sejalan dengan hal itu, Masruroh (2014) menyatakan bahwa salah satu potensi yang bisa dikembangkan dan akan mendatangkan income yang bagus adalah dengan membudidayakan ternak kambing peranakan etawa. Manfaat dari kambing etawa sangatlah banyak baik dari susunya, dagingnya, air seninya bahkan dari kotorannya. Beberapa manfaat terutama dari susunya adalah sebagai proses penyembuhan bagi penderita penyakit TBC (Tuberculosis/TB), untuk proses pemulihan dari berbagai sakit, karena susu kambing etawa berkhasiat untuk membantu menstabilkan kondisi tubuh setelah sembuh dari sakit.

Adapun kendala yang dihadapi para peternak di Keluhan Bahkapul saat ini adalah (1) Produk hasil perahan susu kambing masih dipasarkan di lingkungan sekitar karena produk belum mampu bersaing dengan produk sejenis yang lebih unggu dari segi kualitas (2) Ketahanan produk yang hanya sampai dengan 2 hari saja membatasi pemasaran ke tempat yang lebih luas (3) Para peternak kambing etawa ini tidak pernah mendapatkan pelatihan baik dari sisi pengolahan dan pemasaran produk.

\subsection{Industri Ice Cream}

Semakin ketatnya persaingan didalam dunia usaha pada saat sekarang ini telah membuat para pelaku usaha harus memiliki senjata yang dapat dijadikan sebagai keunggulan untuk memenangkan persaingan dengan para pesaingnya. Kondisi tersebut menyebabkan para pelaku usaha semakin gencar berusaha untuk mencari solusi maupun program bisnis yang dapat meningkatkan daya saing salah satunya adalah usaha produksi ice cream (Hutagaol, Hubeis, \& Soekarto, 2010).

Olahan yang dibuat dari bahan susu ini menjadi salah satu minuman sensasi karena menawarkan aneka jenis rasa yang enak. Produksi ice cream juga mulai 
berkembang di Kota Pematang Siantar tepatnya Kelurahan Banjar karena beberapa masyarakatnya terampil dalam membuat ice cream dengan rasa yang nikmat. Usaha ice cream ini merupakan usaha rumahan yang menggantungkan keberhasilannya pada diri sendiri. Diri sendirilah yang menentukan usaha ini berhasil atau tidak, menjadi besar atau tetap kecil, berputar atau teronggok mati. Usaha kecil serba terbatas: modal terbatas, karyawan sedikit, lokasi berpindah-pindah, dan seterusnya (Kasali, 2012).

Faktanya usaha produksi ice cream di Kelurahan Banjar ini masih menggunakan pengolahan manual dengan alat tradisional seadanya. Kendala lainnya adalah kurangnya pengetahuan penggiat ice cream dalam proses pengolahan secara higenis. Teknik pemasaran produk ice cream ini juga masih dengan berdagang secara keliling di daerah sekitar dengan tidak setiap hari berjualan. Hal ini tentunya akan berdampak pada penjualan yang relatif kurang berkembang. Supaya usaha tidak stagnan maka harus mempunyai keberanian untuk berubah.

\subsection{Tenun Ulos Asli Batak}

Kain ulos merupakan kain khas tradisional orang batak dan sudah tidak bisa lagi dipisahkan dari kehidupan orang batak, karena kain ulos selalu digunakan dalam setiap acara perkawinan, kelahiran anak, punya rumah baru, kematian dan akan pentingnya kain ulos mulai digunakan dalam acara-acara umum ulang tahun, syukuran bagi orang tua yang panjang (saur matua), penyambutan tamu-tamu penting seperti pejabat yang datang akan di berikan kain ulos sebagai sambutan dan cindera mata. Kegiatan tenun ulos awalnya berada di Tapanuli tepatnya di daerah balige dan porsea dan ulos yang ditenun awalnya digunakan hanya untuk kegiatan adat-istiadat saja, akan tetapi kegiatan menenun ulos berkembang menjadi sektor industri dan berkembang ke daerah lain yang juga penduduknya mayoritas orang batak khususnya di daerah Kota Pematang Siantar. Hal ini juga disebabkan karena semakin bertambahnya permintaan dan kebutuhan ulos serta belum adanya industri tenun ulos di Kota Pematang Siantar, dimana tidak memungkinkan secara terus-menerus masyarakat Kota Pematang Siantar membeli ulos dari tapanuli karena jarak antara tapanuli dan Siantar sangat jauh dengan menempuh perjalanan sampai 6 jam lamanya, maka karena kondisi tersebut industri tenun ulos di Kota Pematang Siantar semakin berkembang dan besarnya peluang usaha yang mendukung dalam industri tenun ulos karena penduduk di Kota Pematang Siantar juga didominasi oleh orang batak (Naiggolan, 2015).

Industri tenun ulos di Kota Pematang Siantar merupakan bagian dari industri kecil dan industri rumah tangga. Dalam perkembangan industri tenun ulos di Kelurahan tersebut banyak dijalankan oleh ibuibu rumah tangga atau industri rumah tangga, tetapi ada juga industri kecil tahap menengah yang dijalankan 419 orang akan tetapi industri kecil tersebut tidak bertahan lama, di akibatkan banyak pelaku usaha tersebut kurang bagus dalam hal manajemen, memenuhi bahan baku dan konsistensi dalam menjalankan usaha tersebut, dan juga masih kuatnya pengaruh industri rumah tangga yang menjadi pilihan karena bisa santai menenun ulos sekaligus menjaga anak-anak di rumah dan tidak terlalu dikejar oleh waktu dalam menyelesaikan ulos yang akan di jual, di bandingkan kerja di industri menengah karena waktu kerjanya tidak sebanding dengan upah yang mereka terima (Naiggolan, 2015).

Adapun kendala yang dihadapi para penenun saat ini adalah: (1) Munculnya penenun lain yang berbentuk pabrik sungguh meresahkan bagi para penenun tradisional, meskipun kualitas ulos yang dibuat secara tradisional jauh lebih baik dari ulos buatan mesin (2) Harga dan kelangkaan benang kadang tidak stabil. Harga benang yang naik sering membuat produksi ulos berhenti, penenun akan menunggu kembali jika harga benang sudah turun. Jika harga benang sedang naik maka keuntungan finansial yang di dapat akan semakin sedikit. Produksi ulos dengan kondisi ini bisa membuat para penenun rugi dan modal tidak kembali (3) Kekurangan modal, banyak para pengrajin mengalami masalah modal untuk melanjutkan usaha tenun. Para penenun sulit mengatur pengeluaran dan pemasukan agar seimbang. Hal ini menyebabkan para penenun banyak yang tidak bekerja karena tidak memiliki modal untuk membeli bahan baku (4) Ulos yang dibuat para pengrajin banyak mengalami perubahan, banyak di modifikasi oleh pemilik toko ataupun gallery. Berbagai bentuk sudah dibuat baik itu dalam bentuk jas, kebaya, tas ataupun topi. Hal ini menimbulkan pro kontra antara pemilik gallery dan penenun. Penenun beranggapan bahwa hal tersebut akan mengurangi nilai-nilai yang ada dalam ulos. Pihak gallery beranggapan bahwa cara ini akan membuat eksistensi ulos akan bertahan.

Di sisi lain, pemasaran hasil tenun ulos di Kelurahan Naga Pita Kecamatan Siantar Martoba masih sangat sederhana. Hasil produksi tidak mempunyai cakupan yang sangat luas. Hal ini diakibatkan para pengrajin tenun belum cukup paham bagaimana strategi pemasaran. Segala informasi tentang harga ulos di pasaran diperoleh hanya dari sesama teman- teman pengrajin ulos. Peranan pemerintah dalam memfasilitasi pemasaran hasil tenun sangat minim. Seminar tentang ulos, karnaval ulos atau festival yang berhubungan dengan ulos sangat jarang dilakukan.

\section{PEMBERDAYAAN MASYARAKAT, BANGUN INDUSTRI DESA (BID) DAN CORPORATE SOCIAL RESPONSIBILITY (CSR) TBBM SIANTAR}

Sejak era reformasi di Indonesia, konsep pemberdayaan bahkan telah menjadi kata yang sangat populer terdengar, sehingga sering mengaburkan makna yang sebenarnya. Pemberdayaan dapat dimakani dari power loss menjadi power full, yang selanjutnya pemberdayaan juga sering dapat dimaknai 
sebagai; empowering, enabling dan protekting. Makna istilah pemberdayaan dalam artikel penelitian ini diartikan sebagai kata dasar dari "empower" atau empowering, yang berarti memberi daya kekuatan dan kempampuan atau kekuasaan kepada yang diberdayakan, yakni pelaku industri kecil di Kota Pematang Siantar. Adapun pemberdayaan masyarakat dalam penelitian ini melalui program Bangun Industri Desa (BID) dalam skema Corporate Social Responsibility (CSR) yang dilaksanakan oleh PT. PERTAMINA (Persero) MOR I - TBBM Siantar tujuannya agar setelah diberdayaan melalui program ini mereka pada akhirnya dapat bedaya mandiri sesuai kemampuan dasar yang dimilikinya.

Aplikasi program pemberdayaan masyrakat ini bertujuan untuk meningkatkan minat warga masyarakat dalam berwirausaha serta memudahkan warga masyarakat memahami konsep-konsep dasar dalam kewirausahaan. Aplikasi program kegiatan ini tidak hanya menekankan hasil penelitian secara klasikal, tetapi juga lebih menekankan pada kaji tindak kegiatan praktek di lapangan dengan cara melalui pembentukan kelompok kewirausahaan warga pada suatu usaha lokal (Maisaroh, \& Sukhemi, 2011).

Konsep pemberdayaan dibangun atau dibangkitkan dan diawali dari munculnya konsep paradigma pembangunan mandiri dan sejahtera yang berpusat pada empat sumber (modal utama) sebagai pilar utama pemberdayaan yakni: modal fisik, modal manusia, modal sosial dan modal budaya. Model pemberdayaan masyarakat yang diterapkan berorientasi pada pemberian hak dan kemampuan yang lebih besar kepada individu atau masyarakat sebagai subyek dalam pembangunan tersebut dan bukan sebagai obyek. Konsep ini bertujuan menggali segala potensi dasar yang dimiliki oleh warga masyarakat setempat untuk dapat dibangkitkan dan didorong agar mereka lebih mampu berdaya guna serta berdaya saing tinggi secara mandiri dan berkelanjutan (Maisaroh, \& Sukhemi, 2011).

Bangun Industri Desa (BID) merupakan suatu program pemberdayaan masyarakat yang bertujuan meningkatkan taraf hidup masyarakat dan pembangunan ekonomi berbasis potensi lokal. Lebih lanjut, program ini dijalankan melalui perkembangan potensi lokal yang dimiliki suatu daerah dengan cara membangun sebuah usaha kelompok pengelola produk unggulan lokal guna meningkatkan nilai jual yang lebih tinggi. Adapun usaha kecil yang akan diberdayakan melalui program BID ini adalah usaha produksi susu kambing di Kelurahan Bahkapul. Latar belakang pelaksanaan program BID dengan implementasi CSR oleh PT. PERTAMINA MOR I - TBBM Siantar ini mengacu pada kenyataan bahwa para peternak kambing lebih condong untuk memerah susu kambing dan daging kambing daripada pembibitan susu kambing. Selain itu kebanyakan masyarakat di Kelurahan Bahkapul belum mengetahui dan belum mampu mengoptimalkan potensi kambing peranakan etawa yang sebenarnya mempunyai kemampuan yang cukup tinggi sebagai ternak perah (penghasil susu). Hal ini dikarenakan para peternak kambing etawa ini tidak pernah mendapatkan pelatihan dari segi pengolahan dan pemasaran produk, sehingga produk hasil perahan susu tersebut hanya dikemas dalam botol biasa dan hanya dipasarkan dalam lingkungan sekitar. Sementara itu, beberapa tujuan yang dijadikan motif pelaksanaan program adalah memberikan kontribusi dalam perbaikan Indeks Pembangunan Manusia (IPM), melalui pembentukan kelompok usaha penggiat susu kambing dari sisi peternakan dan pengolahan hasil susu perah yang akan menghasilkan suatu produk. Pelaksanaan program ini juga diperkuat oleh proses pembinaan dan pendampingan intensif.

Tabel 1.1 Deskripsi Program BID Pada Usaha Produksi Susu Kambing

\begin{tabular}{|c|c|c|}
\hline & Hasil Progr & \\
\hline $\begin{array}{l}\text { - Audiensi stakeholder } \\
\text { - Rembug warga } \\
\text { - } \text { Baseline dan endline survei } \\
\text { - Perekrutan peternak kambing } \\
\text { - Pelatihan pemberdayaan ternak } \\
\text { kambing } \\
\text { - Pemberian modal peternak } \\
\text { kambing } \\
\text { - Pendampingan peternak kambing } \\
\text { - Pembentukan kelompok pengolah } \\
\text { susu kambing } \\
\text { - Pelatihan pengolahan } \\
\text { kambing susu } \\
\text { - Rumah produksi } \\
\text { - Pelatihan dan perizinan PIRT dan } \\
\text { Halal }\end{array}$ & 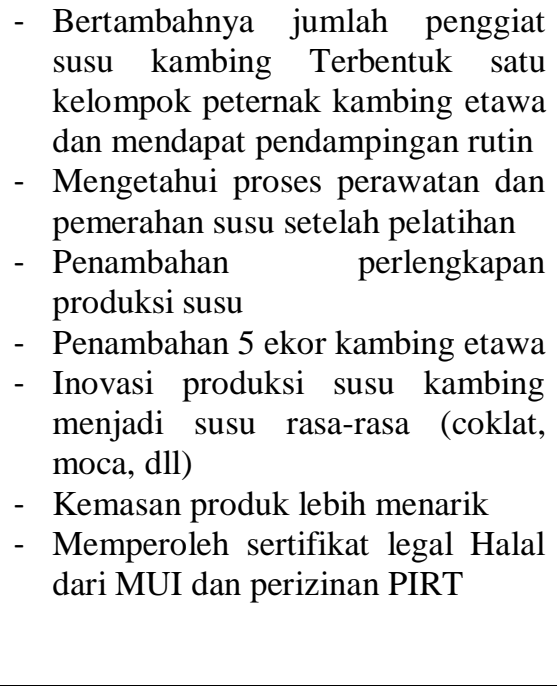 & $\begin{array}{l}\text { - Jumlah produksi meningkat } \\
\text { dari sebelumnya hanya } \\
\text { mampu mengasilkan } 4,5 \\
\text { liter per hari. } \\
\text { - Harga jual produk lebih } \\
\text { tinggi dari sebelumnya Rp } \\
\text { 15.000/botol. } \\
\text { - Menciptakan kesempatan } \\
\text { kerja bagi masyarakat } \\
\text { setempat lebih } \\
\text { - } \text { Kualitas produk keluar } \\
\text { terjamin higenis dan halal } \\
\text { - Pemesaran sudah kan keluar } \\
\text { Kota Siantar ekonomi } \\
\text { - Pendapatan peternak } \\
\text { masyarakat kambing etawa meningkat. }\end{array}$ \\
\hline
\end{tabular}


Program Bangun Industri Desa (BID) juga diberikan pada usaha produksi Ice Cream di Kelurahan Banjar. Latar belakang pelaksanaan program BID PT. PERTAMINA (Persero) MOR I - TBBM Siantar mengacu pada kenyataan bahwa para penggiat Ice Cream dalam meproduksi produknya masih menggunakan olahan manual, cara pembuatannya kurang higenis, kemasan produk juga tidak menarik sehingga kurang mampu bersaing dengan produk yang sejenis. Hal ini menyebabkan jangkauan pemasaran produk hanya disekitar daerah tersebut. Sementara itu, beberapa tujuan yang dijadikan motif pelaksanaan program adalah memberikan inovasi penambahan alat berupa mesin agar meningkatkan efesiensi waktu produksi dan penghematan tenaga karyawan yang dapat dimanfaatkan untuk kegiatan lainnya.

Tabel 1.2 Deskripsi Program BID Pada Usaha Produksi Ice Cream

\begin{tabular}{|l|l|l|}
\hline \multicolumn{1}{|c|}{ Tahapan Program } & Hasil Program & \multicolumn{1}{|c|}{ Dampak Program } \\
\hline - Audiensi stakeholder & - Peningkatan efektivitas dan & - Penghematan waktu produksi \\
- Rembug warga & efisiensi produksi, semula hanya & - Jumlah produksi meningkat \\
- Baseline dan endline survei & menguasai olahan secara manual & - Menciptakan kesempatan \\
- Pelatihan usaha Ice Cream & sekarang mampu menggunakan & kerja bagi masyarakat \\
- Pendampingan usaha Ice Cream & mesin pengolah Ice Cream & setempat \\
- Pembentukan kelompok & - Terbentuk satu kelompok penggiat & - Kualitas produk lebih terjamin \\
penggiat usaha Ice Cream & usaha Ice Cream dan mendapat & higenis dan halal \\
- Rumah produksi & pendampingan rutin & - Pemesaran sudah keluar Kota \\
- Perizinan PIRT dan Halal & - Inovasi varian rasa Ice Cream & Siantar \\
& - Kemasan produk lebih menarik & - Pendapatan ekonomi \\
& - Memperoleh legal Halal dari MUI & masyarakat penggiat Ice \\
& dan perizinan PIRT & Cream meningkat. \\
\hline
\end{tabular}

Implementasi program BID memberikan dampak positif kepada masyarakat Kota Siantar yang di refleksikan melalui peningkatan jumlah produksi susu kambing dan produksi Ice Cream dari sebelum adanya program tersebut. Peningkatan produksi dan penjualan produk karena jangkauan pemesaran yang semakin luas berdampak pada peningkatan pendapatan masyarakat pelaku usaha tersebut. Hal ini sejalan dengan tujuan umum program yaitu untuk meningkatkan pendapatan ekonomi masyarakat peternak kambing etawa dan masyarakat penggiat Ice Cream di daerah tersebut.

\section{PEMBERDAYAAN MASYARAKAT MELALUI CSR OLEH PT. PERTAMINA MOR I - TBBM SIANTAR}

Corporate Social Responsibility (CSR) adalah sebuah komitmen untuk meningkatkan kesejahteraan komunitas melalui praktis-praktis bisnis yang arif dan kontribusi sumber-sumber perusahaan (Kotler, \& Lee, 1999). Adapun tujuan CSR adalah meningkatkan brand image, pengurangan kemiskinan, zero conflict, kelestarian lingkungan, social invest sustainable Development. Saat ini CSR sudah tidak asing lagi di kalangan masyarakat umum, sebagai respon perusahaan terhadap lingkungan masyarakat. Konsep tanggung jawab perusahaan yang telah dikenal sejak 1970-an, merupakan kumpulan kebijakan dan praktik yang berhubungan dengan stakeholders, nilai-nilai, pemenuhan ketentuan hukum, penghargaan masyarakat, lingkungan, serta komitmen perusahaan untuk berkontribusi dalam pembangunan secara berkelanjutan. Implementasi kebijakan CSR adalah suatu proses yang terus menerus dan berkelanjutan (Juniansyah, 2017).

Adapun usaha kecil yang akan diberdayakan melalui bantuan CSR oleh Pertamina Siantar adalah UMKM penenun ulos asli batak di Kelurahan Naga Pita Kecamatan Siantar Martoba. Latar belakang pemberian bantuan CSR ini dikarenakan permasalahan yang dihadapi oleh penenun yang membutuhkan bahan baku benang, manik-manik (simata) dan perluasan pemasaran serta pelatihan bisnis yang lebih kompeten. Secara umum tujuan pemberdayaan melalui program ini untuk meningkatkan kemampuan masyarakat pengusaha pertenunan berdasarkan keunggulan potensi daerah serta dapat berperan aktif untuk meningkatkan perekonomian wilayah sekitar Terminal BBM Pematang Siantar. Hasil dan dampak dari program CSR ini berupa peningkatan pemahaman masyarakat penenun untuk berusaha meningkatkan kualitas bisnis yang telah dilakukan, bahwa inovasi dan invensi perlu dilakukan penenun untuk memperkuat pangsa pasar dari tenun sehingga dapat memperkuat daya saing baik di dalam maupun di luar negeri. Selain itu dampak yang dihasilkan dari program CSR ini memberikan kontribusi kepada masyarakat dalam berkreasi dan berinovasi menciptakan produk lain seperti souvenir, dasi, gantungan kunci dan hasil lainnya setelah mendapatkan pelatihan pengembangan bisnis.

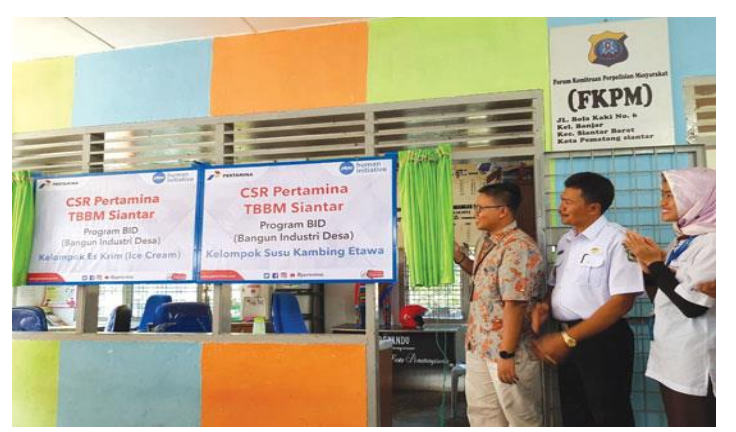

Gambar 1. Peresmian BID Ice Cream and Susu Kambing Etawa oleh perwakilan manajemen TBBM Siantar 


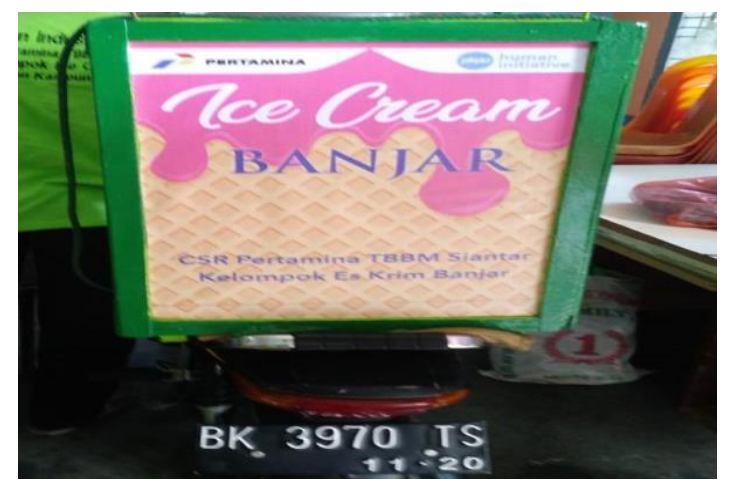

Gambar 2. Moda pemasaran dan Branding produk Ice Cream Banjar

Implementasi program CSR memberikan dampak positif kepada masyarakat Kota Siantar yang di refleksikan melalui perluasan pangsa pasar tenunan ulos asli batak. Selain itu, dalam konteks yang lebih luas program ini juga memberikan dampak sosial ekonomi kepada masyarakatnya, semakin berkembangnya mutu pendidikan, adanya pengakuan di tengah-tengah masyarakat ditandai dengan bisa berbaur dan mau menghadiri kegiatan-kegiatan sosial dan lainnya. Meningkatkan perekonomian masyarakat, menekan jumlah pengangguran, meningkatkan kesejahteraan masyarakat dengan semakin bertambahnya pendapatan masyarakat khususnya bagi ibu-ibu rumah tangga yang turut memberikan dampak kepada peningkatan jumlah pengusaha baru. Hal ini sejalan dengan tujuan umum program yaitu untuk meningkatkan pendapatan ekonomi masyarakat sebagai penerima manfaat implementasi program CSR BID dan pengembangan kerajinan berbahan dasar ulos khususnya di Kota Siantar.

\section{KESIMPULAN}

Upaya peningkatan kemampuan dan potensi masyarakat sangatlah penting, dengan adanya peningkatan kemampuan dan potensi yang dimiliki masyarakat, maka mereka bisa bersaing dengan masyarakat lainnya, meningkatkan taraf hidup serta bisa mengembangkan kemampuan mereka terutama di bidang ekonomi. Pemberdayaan masyarakat memiliki makna bahwa penyelenggaraan pemerintahan dan pelaksana pembangunan daerah melalui potensi lokal ditujukan untuk peningkatan taraf hidup dan kesejahteraan masyarakat melalui penerapan kebijakan, program dan kegiatan yang sesuai dengan esensi masalah dan prioritas kebutuan masyarakat (Soemantri, 2011).

Berdasarkan hasil analisis dan pembahasan yang dikaji berdasarkan literatur yang relevan dapat disimpulkan bahwa strategi pemberdayaan masyarakat melalui program BID dan CSR cukup memadai dilakukan di Kota Siantar dilihat dari dampak positif yang diberikan program tersebut terhadap peningkatan kualitas produk yang dihasilkan. Pemberdayaan masyarakat melalui pelatihan dan pendampingan pengolahan susu kambing, Ice Cream dan tenun asli Batak dapat meningkatkan secara bermakna pengetahuan pedagang industri lokal di bidang strategi pengolahan dan pemasaran. Pemberdayaan masyarakat ini menyadarkan komunitas usaha setempat bahwa mereka memiliki sejumlah potensi yang dapat dikembangkan, termasuk untuk memasarkan ulos ke manca negara perlu dilakukan pembenahan pola pikir untuk bisa berinovasi serta kepedulian untuk mengembangkan makna ulos. Para penenun juga harus selalu belajar dengan melihat permintaan pasar serta mengambil inspirasi desain baru melalui internet termasuk pemasaran berbasis e-commerce. Sebagaimana yang digarisbawahi oleh Sulistiyani (2004) bahwa untuk mewujudkan derajat keberdayaan salah satu langkahnya adalah upaya penyadaran untuk memahami diri, potensi, kekuatan dan kelemahan, serta memahami lingkungannya. Adapun saran yang dapat diberikan bagi pengembangan penelitian serupa dengan mengukur dimensi yangberbeda, baik secara kuantitatif maupun kualitatif sehingga dapat menyempurnakan kerangka evaluasi yang dilakukan.

\section{DAFTAR PUSTAKA}

Adamson, D. (2010). Community empowerment: Identifying the barriers to "purposeful" citizen participation. International Journal of Sociology and Social policy. 30(3/4), 114-126.

Badan Pusat Statistik. https://www.bps.go.id

Clark, D., Southern, R., \& Beer, J. (2007). Rural governance, community empowerment and the new institutionalism: A case study of the Isle of Wight. Journal of Rural Studies. 23(2), 254266.

Deswimar, D., \& Almari. (2014). Peran Program Pemberdayaan Masyarakat Desa Dalam Pembangunan Pedesaan. Jurnal El-Riyasah. 5(1), 41-52.

Dilham, A., \& Putra, U. M. (2016). Pemetaan Sosial Ekonomi Masyarakat Pematang Siantar (Studi Kasus Masyarakat Siantar Barat). Human Falah. 3(1), 75-92.

Hutagaol, R. E., Hubeis, M., \& Soekarto, S. T. (2010). Kajian Strategi Pemasaran Es Krim Baltic di PT. Balticindo Jayafood Jakarta. Manajemen IKM. 5(2), 122-131.

Juniansyah. (2017). Pemberdayaan Masyarakat Melalui Corporate Social Responsibility (CSR) PT. Kaltim Nitrate Indonesia. Journal Ilmu Komunikasi. 5(3): 87 - 101.

Kasali, R. (2012). Cracking Entrepreneurs (Inilah Para Crackers Lokal Yang Tak Ada Matinya!). Jakarta: PT. Gramedia Pustaka Utama.

Kotler, P., \& Lee, N. (1999). Pengantar Bisnis.

Laverack, G. (2006). Using a 'domains' approach to build community empowerment. Community Development Journal. 41(1), 4-12.

Lyons, M., Smuts, C., \& Stephens, A. (2001). Participation, empowerment and sustainability: (How) Do the links work?. Urban Studies. 38(8), 1233-1251. 
Maisaroh, S., \& Sukhemi. (2011). Pemberdayaan Masyarakat Melalui Pengembangan Budaya Kewirausahaan Untuk Mengurangi Pengangguran Dan Kemiskinan. Jejak. 4(1), 23 33.

Masruroh, I. (2014). Pemberdayaan Masyarakat Melalui Kelompok Budidaya Ternak Kambing Peranakan Etawa di Dusun Kemirikebo Kelurahan Girikerto Kecamatan Turi Kabupaten Sleman Yogyakarta. Skripsi. Universitas Islam Negeri Sunan Kalijaga. Yogyakarta.

Nainggolan, E. (2015). Perkembangan Industri Tenun Ulos Di Kelurahan Sigulang-Gulang, Kecamatan Siantar Utara Dan Pengaruhnya Terhadap Sosial Ekonomi Masyarakat Tahun 1998-2005. Journal of Indonesian History. 3(2), 15-30.

Pamungkas, A. (2010). Pemberdayaan Masyarakat Melalui Usaha Industri Kecil Batik Semarang16 Di Bukit Kencana Jaya Tembalang Semarang. Skripsi. Universitas Negeri Semarang. Semarang.

Phillips, E. N., Berg, M. J., Rodriguez, C., \& Morgan, D. (2010). A case study of participatory action research in a public New England Middle School: Empowerment, constraints and challenges. American Journal of Community Psychology. 46, 179-194.

Pranoto, A. R., \& Yusuf, D. (2014). Program CSR Berbasis Pemberdayaan Masyarakat Menuju Kemandirian Ekonomi Pasca Tambang di Desa Sarijaya. Jurnal Ilmu Sosial dan Ilmu Poitik. 18(1), 39-50.

Soemantri, B. T. (2011). Pedoman Penyelenggaraan Pemerintahan Desa. Bandung: Fokusmedia.

Sulistiyani, A. T. (2004). Kemitraan dan Model-Model Pemberdayaan. Yogyakarta: Penerbit Gava Media. 